\title{
The relation of God's mission and the mission of the church in Ephesians
}

\section{Timothy van Aarde ${ }^{1}$}

\begin{abstract}
A separation between the mission of God and mission of the church occurred post Willengen 1952 through an introduction of the term and concept missio Dei. In the Pauline corpus the letter to the Ephesians makes an invaluable contribution to mission. In the time period 1811-1950 central to the theologies of mission that emerged was the relation of the mission of God and the mission of the church. The mission of God and the mission of the church are interrelated and developed in terms of two concepts in Ephesians, oixovouía (1:9-10; 3:2, 9-10) and $\pi \lambda \eta \dot{p} \omega \mu \alpha$ $(1: 20-23 ; 3: 19 ; 4: 10,13)$.
\end{abstract}

Keywords: Ephesians, mission of the church, oikonomia, pleroma, missio dei, fullness.

\section{Introduction}

In the letter of Ephesians the mission of God and the mission of the church are interrelated and interdependent. The book of Ephesians informs a theology of mission and provides both direction and empowerment for developing practices of missions. In a theology of missions both historical developments in the theology, biblical foundations and ongoing activity in missionary practice has continually to be re-engaged. The content of missiological thinking has changed and continues to change through re-engagement but in some ways it has remained the same. The church has struggled with conceptualizing and understanding a view of mission(s) that is simultaneously God centered and church focused (cf. Tennent 2010:60). God has a plan and everything is worked out according to that plan (cf. Hoehner 2004:284). In that plan the Church is more than a sign post or an end in itself, it has a participatory and prominent role in the unfolding and execution of God's plan. "The church is but a means to an end, not an end in itself' (Greenwood 2002:86) ${ }^{2}$. The role of the church in Ephesians in relation to the spiritual powers has been reduced to the church as institution passively bearing witness to the 'powers' as to their imminent future demise. The church has been interpreted as being passive in the "filling" or "completion" of all things in Ephe-

1 Dr. Timothy van Aarde is a researcher for the Department of Humanities, North West University. He can be contacted at timoman111@gmail.com.

2 "The end is that God's kingdom may come on earth as it is in heaven (Diocese of Derby)" (Greenwood 2002:86). 
sians 1:20-23. It is in Ephesians 1:20-23 that the already of the kingdom that Jesus has set in motion and the not yet that characterize the present time are reconciled and provide an understanding of the relationship between the kingdom of God and the church. The connection between the concept of the missio Dei, the church, and the kingdom of God is brought out in the relation of two key concepts in Ephesians, oixovoria and $\pi \lambda \dot{p} \rho \omega \mu \alpha$. The mission of the church serves the mission of God, the missio Dei. The relation of the mission of God and the mission of the church in terms of these key concepts demonstrates that God's purposes for the church are not separated from his purposes for the world.

\section{The relation of the mission of God and the mission of the Church in the historical period 1811-1950}

In the development of missiology certain key missiological concepts and world contexts are identifiable. The concepts and contexts are missions (1811-1910), church and missions (1910-1950), church and mission (1950-1975), convergence and divergence (1975-1995) and missional church (1995-present). Missiological developments occurred as the nature of the theology of mission developed through historical mission's periods of time from 1811 until the present. In this article the time period 1811-1950 will be examined in which the central idea was the relation of the mission of God and the mission of the Church. In the period 1948-1975 a "decisive shift took place from understanding mission as one part of the church's task to the decisive shift from understanding mission as one part of the church's task involving the sending of special personnel to a particular geographical location, to recognizing that mission is the task of the whole church involving all God's people through participation in the fulfillment of God's purposes throughout the world, as they have been revealed in Christ through the witness of the Holy Spirit" (Bassham 1990:56-57). The letter to the Ephesians provides a theological foundation for the relation of the mission of God and the mission of the Church. The biblical foundation for this relation was laid on tenuous grounds in the period 1811-1950 with the result that a separation occurred between the mission of God and the mission of the church after Willengen in the 1950's ${ }^{3}$. Since the 1950's the mission of the Church has been replaced by God's purposes being realized in the world through a kingdom theology in which the church no longer has a central role. "The church's mission is to be a sign of the presence of that kingdom through its words and actions" (Bassham 1990:57). The mission of God is a mission that is on route to its fullness and completeness when the times have reached its fullness

3 Engelsviken (2003:486) sees no conflict between the mission of God and the mission of the church. He affirms a view of the missio Dei of Willengen 1952 in which the church is the instrument of the missio Dei (cf. Engelsviken 2003:486). 


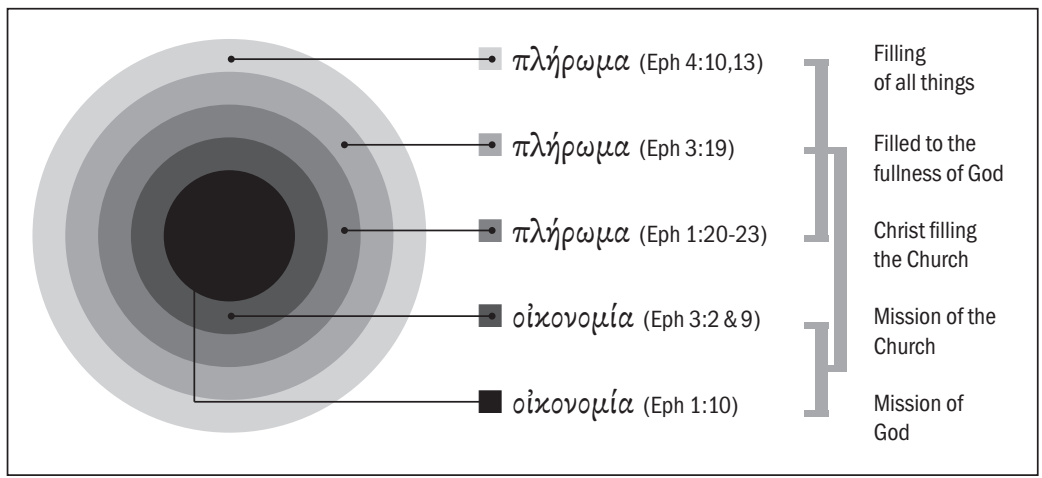

Diagramm 2.1

or completeness (Eph 1:10) and inseparable from apostolic mission (Eph 3:2-8) which became the mission of the Church (Eph 3:9-10). In Ephesians the mission of God and the mission of the church expressed by the concept of oixovopia (Eph $1: 9-10 ; 3: 2,9-10)$ is inseparable from the reign and kingdom of God expressed by the relation of the concept $\pi \lambda \eta \dot{\rho} \omega \mu \alpha$ (Eph 1:20-23; 3:19; 4:10, 13).

Diagram 2.1 illustrates by means of centric circles the relation of the key concepts oixovo $\mu^{\prime} \alpha$ and $\pi \lambda \eta^{\prime} \rho \omega \mu \alpha$ in Ephesians in the cosmic re-unification ${ }^{4}$.

\section{The use of oixovouía (Eph 1:10; 3:2, 9-10) and Missions: a missiology for foreign missions 1811-1910}

The theology of mission of the period 1811-1910 was a missiology for foreign missions. It was a missionary movement that had its origins in the Great Awakenings of the 1800 's 5 . "Above all, the new mood spawned a missionary spirit" (Bosch1991:279). The focus of this period was conversion of the individual, obedience to the Word of the Lord and the obligation to gather the church. The cosmic meaning of the church means that the mission of the church is not simply to rescue a few souls from the tumultuous sea of history but the cosmic manifestation of the manifold wisdom of God, who created all things (Eph 3:9-10) (cf. Padilla 2010:208). The focus of missions in this period was placed on the winning of converts to the faith. The expansion of the gospel to the nations in the period 1811-1910 was measured in terms of the geographical spread of the gospel. In the time, there came a thinking and a perception that there was no need for missions work in the already Christianized west, so missions largely became something

4 The central idea of the letter is "the summing up of all things" (Eph 1:10).

5 “Carrey's famous slogan, "Expect great things from God, attempt great things for God” expressed the prevailing mood” (Bosch 1991:279). 
that happened in faraway pagan places. The Great Commission (Matt 28:18-20) provided the theological basis of the theology for missions. Missionary societies in this period "were hailed as 'standard-bearers of the churches' as they advance with the gospel of Christ for the conquest of the world" (van't Hof 1972:39; Bosch 1991:295). "Prior to the 1950's most scholars assume or argue that the church expanded spontaneously according to Paul's expectations" (Plummer 2006:21) ${ }^{6}$. It is the period 1950-present that a continuation between Paul's mission and the expectation of his congregation to engage in missions developed (cf. Plummer 2006:22). Although most scholars admit that an argument for continuity or discontinuity must be established on firmer textual grounds (cf. Plummer 2006:22) a biblical basis for the relation of the mission of God and the mission of the church has not been given. The result has been that the church was effectively sidelined as the community through whom God fulfills his mission in the post-Willengen view of missions (cf. Tennent 2010:56).

\subsection{The use of oixovoria and the mission of God.}

In Ephesus the missionary movement was both structured (Acts 19:8-10) and spontaneous (Acts 19:11-20). It is "from Ephesus the gospel spread throughout all the neighboring county so that many churches sprang up, the members of which had never seen St Paul's face" (Gallagher 2013:11) which implies a missionary movement. It has been argue that there is no textual evidence for the mission in the Pauline letters committed to the church ${ }^{7}$. The use of the concept oixovopía in Ephesians provides a structured basis for missions and corresponds to a missiology for foreign missions. In Ephesians "the stewardship (oixovouía) of the grace given to me for you," (Eph 3:2, 9-10), the "you" indicates that that the stewardship of the gospel was intended for the $\varepsilon^{\prime} \theta \nu \eta$, the Gentile nations (Eph 3:1). The use of oixovoria provides the continuity between the missio Dei (1:3-14, 1:10), the apostolic mission (Eph 3:2-8) and the church's mission (Eph 3:9-10). The author of Ephesians demonstrates that a relation exists between Christ' continuing work (Eph 1:10, 1-14), the apostolic mission (Eph 3:2, 3-8) and the church's mission (Eph 3:9-10). The task of missions was central to the apostolic commission. Paul commits to the church the apostolic mission, the mission he has received from the Lord (Eph 3:2). He enlightens the church as to "what is the stewardship of the

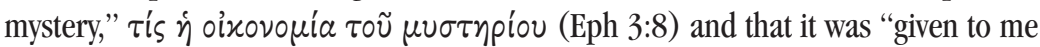
for you" (Eph 3:9). "A key ingredient of the Church's task is 'to help discover what

6 Rollan Allen in Missionary Methods and The Spontaneous Expansion of the Church emphasized the spontaneous expansion of the church.

7 Bowers (1991:111) claims that no textual evidence can be found for support of the view that Paul expected his churches to be active in outward-directed evangelism. 
our particular role is and help us to play it better' (Healy 2000:65). The task of the stewardship of the gospel that was passed on to the church rather than simply the mystery, the kerygma, apostolic authority or a missionary office. The use of oixovouia in Ephesians reflects the relationship between the sending of the Son, the missio Dei, the apostolic mission and the mission of the church. Support for an active mission for the Pauline churches have been based on the concept of, "the word of the Lord ringing out" (1 Thess 1:8; cf. Rom 1:8; 2 Cor 3:2). The term oixovoria is used to indicate a continuation of the mission of God. The mission of the church, however, is not perfectly identifiable with the mission of God (missio $D e i$ ) as Yong (2010:48) suggests. The framework, the roles, attitudes, and activities of the church cannot be absolutized since the work of mission will be superseded by the reign of God, even as the luring force of the mission of the church is the kingdom of God that is ahead of us (cf. Yong 2010:48). The task of oixovouia (Eph $1: 10 ; 3: 2 \& 9)$ as it is related to the $\pi \lambda \eta^{\prime} \rho \omega \mu \alpha$ (Eph 1:23, 4:10, 13) ensures that that the mission of God is not identified exclusively with the mission of the church. It is in the relation of oixovoria to $\pi \lambda \eta^{\prime} \rho \omega \mu \alpha$ in Ephesians that the mission of the church is understood as participating in the establishing of Christ's rule over the redeemed creation rather than being perfectly identifiable with Christ's rule. The church establishes Christ's rule in word and deed, holistically proclaiming that Christ's reign is present and will be fully realized at the consummation, but the church is not the exclusive sphere of Christ's reign.

3.2 The commitment of the task of oixovopia to Paul (Eph 3:2) and the church (Eph 3:9-10) in participation of the mission of God (Eph 1:10).

The apostolic mission has been committed to the church as a whole and Paul understands missions as an ecclesiastical task. The spread of the gospel and the missionary task was entrusted to Paul as an obligation, which he again had to commit and entrust to the church. The ministry which Paul received from the Lord Jesus, to bear witness to the good news of the grace of God (Act 20:24) is committed by him to the elders of Ephesus (Acts 20:30-35).

The task of oixovopi $\alpha$ committed by Paul to the church includes three essential elements:

\section{Primary evangelism}

2. The nurture and building up of emerging churches, and

3. Their firm establishment as congregations

Peter 0'Brien (1999:43) identifies these elements as essential to the mission of the apostles. The mission that is committed to the Ephesian elders consisted of these tasks. It is a reasonable therefore to assume that the stewardship of the mystery which Paul commits to the elders of the church of Ephesus involved these 
essential elements. The term oixovouia denoted the stewardship of the mystery of God (1 Cor 4:1) and involved the communication of the gospel to both believers and non-believers, insiders and outsiders (cf. 1 Cor 9:17-19). The oixovouoss, a class of servants, where to be faithful to reveal the mysteries of God (cf. 1 Cor 4:2). The verb for the preaching of the gospel means to 'preach the gospel', not to 'proclaim' or 'preach' in general but preaching directed to both believers and

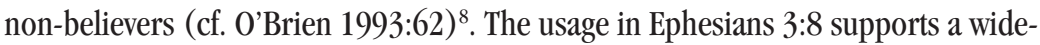
ranging series of activities being summed under the notion of preaching the gospel (cf. 0'Brien 1993:63). This suggest something more than initial evangelism and includes church planting, leadership development, anthropology and a development of local cultures. The task of oixovopía entrusted to Paul was far more than simply to found and plant churches. The task then entrusted to the church involved much more. The phrase "the riches in Christ" (Eph 3:8) is a comprehensive phrase which suggests that a careful teaching, instruction and application was called for- that is, something more than is suggested by initial evangelism (cf. 0'Brien 1993:63). There are two pit falls, the first is to separate God's mission from the church. The second is to equate mission and the church as though God only works in and through His church. The church has to recognize that if the mission of the church is perfectly equated with the mission of God then the church claim's an exclusivity as to God's mission.

The mission of God historically involved two related movements. God called the apostles to carry out his plans. And God has called the Church to continue the apostolic ministry9. In the fulfilment of its apostolic mandate the Church has to prayerfully instill in its members a sense of God's call, which the author of Ephesians endeavors to do in the First prayer (Eph 1:15-23). The reality is that many churches do not have a vision for foreign missions ${ }^{10}$ because they are not purposeful to pray for foreign missions. A rediscovery of the task of oixovouia having been committed to the church is an essential for the church to fulfill its task and calling to foreign missions. "The mission of the church needs constantly to be renewed and re-discovered" (Tennent 2010:101).

\subsection{The role of the Church in the execution of the mission of God.}

The introduction of the concept missio Dei by Vicedom resulted in the mission of God being separated from the church's proclamation and activity (cf. Tennent 2010:55-56), historically it was a separation of a missiology for mission from missiology of missions.

8 ). In Ephesians 3:8 the noun gospel is used as a verb and literally means to "gospelize". A sense that it also has in Romans 1:15 (cf. 0'Brien 1993:63).

9 It is the apostolic ministry as opposed to the apostolic office that continues through the church.

${ }^{10}$ The crossing of geographical boundaries must not be neglected or considered as being obsolete. 
The employment of the term oixovopia in Ephesians for the mission of God (Eph 1:314) and for the stewardship of the gospel for the Gentiles given to the apostle Paul (Eph 3:2, 3-8) is identifiable with a missiology for missions. The mission of the church (Eph 3:9-10) is also identified with a missiology for foreign missions and so oixovoria captures the original intention of Vicedom which was not to separate God's mission from the church's mission (cf. Tennent 2010:56). "The church is part of the missio Dei, but the mission of the church cannot simply be identified with God's mission" (Engelsviken 2003:487). "Both the church and the mission of the church are "tools of God, instruments through which God carries out His mission"'(Engelsviken 2003:482; cf. Vicedom ). The flaw that occurred in the application of the missio Dei in the last century resulted in the undue separation of God's mission from the mission of the church (cf. Tennent 2010:56). The World Council of Churches, since the introduction of the term in 1963 in Mexico City, envision God's mission as broader than the church. The mission of God and the mission of the church were thinly connected. The understanding of missio Dei after Willengen was no longer exclusively bound to the sending of the Son and redemption (cf. Engelsviken 2003:482). "Certainly in his classic articulation of the missio Dei, [sic] Vicedom in no way intended for God's mission to be separated from the church's proclamation and activity" (Tennent 2010:56). The purpose of the mission was reduced to the sole aim of saving souls as opposed the restoration of creation. The mission of the church is a continuation of the redemptive act of God: "The mission can be nothing else than the continuation of the saving activity of God through the publication of the deeds of salvation. This is the greatest authority and supreme commission" (Vicedom in Engelsviken 2003:483). The concept of the missio Dei involves more than simply the relation of the mission of God and mission of the church and so it cannot be summated by the use of a single concept such as oixovopía. "In the contemporary mission thinking no one would contemplate trying to grasp the missio Dei without a thorough reference to the rule and reign of God" (Kirk 1999:28). It therefore also involves the reign and rule of God, expressed in Ephesians by $\pi \lambda \eta \dot{p} \omega \mu \alpha$. It was the separation of the rule or reign of God from the mission of God and the mission of the church that opened up the new and more radical views of the missio Dei and mission. It is a miss understanding to conceive of the activity of God in the world as being different from what God is doing in and through the church (cf. Engelsviken 2003:485). But at the same time the mission of God cannot be conceived as exclusively belonging to the church.

\subsection{The relation of the apostolic mission and the mission of the Church}

The relation of the apostolic mission and the mission of the church worked out in a theology of missions will take as central the Bible addresses, a flaw that occurred in the application of the missio Dei (cf. Tennent 2010:56). Paul sets out his role in the unfolding of the plan of salvation through the proclamation of the gospel (Eph 
3:2-8), and it is through the proclamation of the gospel that heaven and earth, angels and people are brought into unity in Christ. Paul does not uncritically advocate his apostolic mission as a pattern for the church's mission, rather he develops a missional theology which would serve as a missiology for foreign missions for the church. He is careful to distinguish between his unique role in mission which was as a pioneer of the Gentile mission (Eph 3:2-8), and the stewardship and mission he commits to the church (cf. Eph 3:9-10), essential ingredients of missiology for foreign missions. It was the revelation of the mystery made know to Paul (Eph 3:3) that brought with it "the stewardship of the mystery" (Eph 3:2). The task of Paul was twofold, "to preach the unsearchable wealth of Christ" (Eph 3:8) and "to enlighten all men" (Eph 3:9) as to their role in the proclamation of the gospel. The task he had received was furthermore to enlighten the Church as to its participation in the proclamation of the gospel. The mission of God "is carried out through the church as its primary locus” (Engelsviken 2003:486).

\subsection{A Theological Basis for the church's mission}

\subsubsection{The relation of the Church's mission to the Great Commission}

It has been suggested that there are some texts that seem to indicate that the church is instructed to engage in missionary activity (e.g. Eph 6:15; Phil 2:16; Tit 2:10), and praise them for their missionary activity (e.g. Phil 1:14-18; 1 Thess 1:8), but that it is doubtful that Paul viewed his (often incidental) comments as a compelling theological basis for the church's mission, argues Plummer (2006:48). The absence of the provision of an explicit exhortation or direction for the church to replicate Paul's apostolic mission and so no clear expectation that the church will be active in missionary work is based on the inference that Paul nowhere references his apostolic authority as a basis for instructing the church to engage in missions (cf. Plummer 2006:48). In Ephesians 3 we find an example of Paul not defending his apostolic authority, as has been assumed, but a theological basis for the foundation of his apostolic mission upon the mission of God, a theological basis for the founding church's mission upon the mission of God. The attempt has been made to base the mission of the church on Paul's missionary vision of Jesus' Great Commission (Matt 28:18-20) identifying Paul's Gentile mission as being a continuum of the Great Commission. It was Gustav Warneck who based Paul's missionary vision on Jesus Great Commission in an attempt to avert the founding of the church's mission on moral and humanitarian concerns ${ }^{11}$. He based it on the assumption that Paul and his churches were familiar and motivated by Jesus' Great Commission. There

${ }^{11}$ Gustav Warneck confronts scholars such as Ernest Troeltsch (1865-1923) who founds the church's mission on moral and humanitarian concerns. 
is, however, no convincing evidence in the Pauline epistles for a direct connection between the Great Commission and the Church's mission (cf. Plummer 2006:49).

\section{The use of $\pi \lambda \eta \dot{p} \rho \mu \alpha$ (Eph 1:20-23) in the relation of Church, Missions and a missiology of foreign mission 1910-1950}

A missiology of foreign missions was the predominant theology of missions of the period 1910-1950. Although the winning of converts to the faith was still the focus, church planting, leadership development, anthropology and the importance of local cultures were developed so that a shift in emphasis occurred from the centrality of the geographical location of missions to the development of the younger indigenous churches by the older foreign churches. The vision of the period "involved seeing mission as the task of the whole church, with the churches drawing closer together in unity to share in the work given by God to all Christians, rather than as a geographical undertaking conducted by a small group of people in a foreign land" (Bassham 1980:52). The prevailing idea of the era was that the fulfilment of the Great Commission was a tangible and realizable goal which was shattered by World War I and II. In this period World War I and II brought about a debate of the relation of missions to the kingdom of God and His reign ${ }^{12}$. The shattering of idealistic expectations brought with it a re-orientation of mission and realization that "our mission will not user in God's reign" (Bosch 1991:35). It is Roland Allen's pneumatological missiology that in the beginning of the 1920's provided a pneumatological framework for missions ${ }^{13}$. The framework of letter to the Ephesians has three pillars ecclesiology, pneumatology and eschatology, which are essential ingredients of a missiological framework. In this period "not a single sermon or missionary report can be discovered that does not have an eschatological consideration (cf. Bosch 1991:287). In Ephesians mission theology links together mission and unity as integral and inseparable parts of God's will for the church ${ }^{14}$. The mission task of the church is a task to be completed in community and the prayer of Ephesians 1:15-23 is for the church to be a community of mission.

\subsection{The missional characteristics of the First prayer (Eph 1:15-23).}

The letter to the Ephesians is simultaneously directed at a specific congregation, the church of Ephesus, and the churches of Asia Minor. The first prayer is for a specific

12 Johannes Weis and Albert Schweitzer proclaimed God's reign as present in Jesus and regarded Jesus, "as proclaiming only a future coming kingdom" (Bosch 1991:32).

13 Pomerville (1985) corrects what he calls the "pneumatological deficit" in mission theology. He proposes that God has a diversity of intentions in salvation history and he corrects the distortions of theology and mission theory as they have been developed in the West (Pomerville in Yong 2010:47-48).

14 Payne \& Moses (1957:29) "the unity of the church and the mission of the church both belong, in equal degree, to the essence of the Church...." 
local congregation and at the same time for the universal church and body of Christ. The prayer for the Church of Ephesus sets the proper tone for the entire mission theology of the letter to the Ephesians (cf. Senior \& Stuhlmueler 1983:202). It provides a theological framework and motivation for the fulfilment of the church's mission. The mission of the church is to fulfill the plan of God. "The church's mission is to show the world what it looks like when a community of people lives under the reign of God" (Webber 2002:133). The prayer contains a petition about the wealth of the wisdom the church possess (v.17) and that the church will be enlightened to what is the calling it has received (v. 18). It concludes with a statement of faith that Jesus is supreme head over all things, creation and the cosmos, "for the church" (Eph 1:22). The mission of the church will be fulfilled and complete when Christ has filled all with all (Eph 1:23). In the execution of the mission of the church "no opposition can ultimately prevail over his people" (Grizzle 2013:42). "Prayer functioned as an important tool through which the divine plan of salvation was made known" (Gallagher 2013:18). It is the means through which the church participates in the purposes and plan of God.

\subsubsection{A prayer for enlightenment and inner transformation}

Since the departure of the author there are young and new believers who have become part of the church, "having heard about you faith" (Eph 1:15), and so he prayers specifically for them giving thanks for their love for all the saints. He prayers that God the Father "may give to them a spirit of wisdom and revelation in a fuller knowledge of Him" (Eph 1:17), in a deeper and more intimate knowledge of Him. It is experiential knowledge that is in view.

\subsection{The missional nature of the confession of faith (Eph 1:20-23)}

It has been proposed that the central confession of faith of the Ephesians 1:3-3:21 is located in 1:20-23 (Meyer 1977:24-26; cf. Jordaan 1990:49-70). The epistle is essentially about Church as it fulfills the purposes of Christ. The letter is about God's mission and the church's participation in fulfilling his mission. The relation of God's mission to the church's mission is related together in Ephesians 1:20-23. "It is in the affirmation of his universal Lordship that the church finds the basis for its mission" (Padilla 210:206). The confession has a missional nature in that the confession is the basis of the church's mission. It is far more than a personal confession of faith but the confession of the church as to Christ's exalted position as head over the cosmos and so it demands a response ${ }^{15}$. It is about the response of the church to the Lordship of Christ.

${ }_{15}$ In Ephesians 4:4-6 the formula is that of a doctrinal confession of faith. 


\subsubsection{The heavenly and earthly realms and authority and status (Eph 1:21)}

A separation between the heavenly and earthly realms came through the fall of mankind into sin. It was, however, not a separation of the spiritual from the physical, symbolized by two places heaven, the spiritual, and the earth, the physical, but a separation in terms of the source of rule, authority, and power. The heavenly realms is a domain that recognizes God's sovereignty, not only over the visible world but also over the larger, even more real, unseen world (cf. Van Rheenan 2014:47). "The earthly realms refers to a worldview that limits reality to the observable, physical , visible realm or functionality behaves as if reality were limited to this realm" (Van Rheenan 2014:47). Christ is seated at the right hand of Him (Eph 1:20) in the heavenly realms to indicate that his authority, power, or status relative to others is "far above all rule and authority and power and lordship" (Eph 1:21). The word ن $\pi \varepsilon \rho \alpha \dot{v} \omega$ (Eph 1:21) is used of Christ's exalted status above the powers ${ }^{16}$. The redeemed mankind have been transferred from the domain were they were under the power of Satan and his principalities and powers (Eph 1:21;2:1-3; 6:12) to the domain of Christ's rule, authority and power. They have a new status, a status that is far above the powers and principalities. "Christ's own exaltation and enthronement in the heavenlies (1:20) is compared with the believer's exaltation and enthronement (2:6)" (Van Rheenan 2014:351). This, however, does not mean that the redeemed mankind inhabits the heavenly realms, far above the principalities and powers as Christ does. Christ alone has an exalted position at the right hand of God (Eph 1:20), which we will share in at the Parousia. In the present age the Church share in Christ's status and authority to the extent that it continues in submission to its head, Jesus Christ (Eph 1:21-22).

\subsubsection{The Body of Christ (Eph 1:22-23)}

"The church's understanding of herself as the body of Christ (1 Cor 12:27; Eph 1:22-23; 4:15-16) profoundly impacts how she sees her mission" (Van Rheenan 2014:99). In the translation of the gospel "Missions is the very means by which the church becomes the body of Christ, realizing and manifesting the fullness of Christ" (Tennent 2010:89). It is as the church grows and emanates more of the glory of God that it testifies to the abundant diffusion of His own "fullness" and "glory" (cf. Edwards 1972:461-462 in Tennent 2010:89). The vibrancy, purpose, and direction of the body of Christ comes from its mission (cf. Van Rheenan 2014:99). It is as the body of Christ seeks to complete or fulfill its mission that the body grows to fullness (cf. Eph 1:23). Schnakenburg (1991:80) identifies the Body of Christ, the

\footnotetext{
${ }_{16}$ The preposition $\dot{\tau} \pi \varepsilon \rho$ denotes status and not place (cf. Harris 2012:250).
} 
Church, as the $\pi \lambda \eta \dot{p} \omega \mu \alpha$ of him who fills the universe ${ }^{17}$. The idea could only be that of the Church filling the cosmos in the sense of the active role of the Church in missions, or Christ filling the mission of the Church ${ }^{18}$. If then, it cannot be interpreted as a spatial filling then it has to have in view completing a task and so missions. "Our understanding and insight into the full nature of God in Jesus Christ continually expands as more and more people groups come to the feet of Jesus" (Tennent 2010:89). The power of God for accomplishing the mission of the church is expressed in the context of the relation to the body to its one head, Jesus Christ. The "surpassing greatness of the power of him" (Eph 1:19) is for more than a personal conceptualization of salvation, an individualistic reading of the text. The

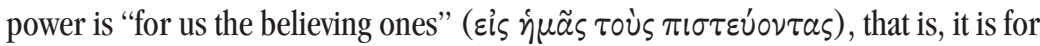
the Church to fulfill its mission. The use of $\varepsilon i \zeta \eta_{\mu} \tilde{a} \varsigma$ (Eph 1:19) indicates that the surpassing power is given for a specific purpose, "for us", the Church to be able complete or fulfill its "calling" (Eph 1:18). The dynamic and dependent relationship of the body to its head is the means through which the church is equipped and empowered for its mission. "All things has been subordinated under the feet of Him" and it is in the dominion that Christ exercises that He has been given "to the church" (Eph 1:22). It is as the exalted Lord whose authority extends to the whole universe that He exercises his dominion for the benefit of the church.

\subsection{The use of $\pi \lambda \eta \dot{p} \omega \mu \alpha$ in the confession of faith (Eph 1:20-23)}

The term $\pi \lambda \eta \dot{\rho} \omega \mu \alpha$ has the meaning of to 'fulfill' or 'complete' (Eph 1:23). The term $\pi \lambda \eta \dot{\rho} \omega \mu \alpha$ "normally has the idea of 'completeness, the absence of any lacunae' (Hoehner 2004:295). In Ephesians the literal meaning of the verb $\pi \lambda \lambda_{n} \rho{ }^{\prime} \omega$ means "to fill" containers or in the passive it means "to be filled". In the relation of Ephesians 1:20-23 to 1:10 $\pi \lambda \eta^{\prime} \rho \omega \mu \alpha$ has the meaning of the fulfilment of God's plan as it is unfolds in the cosmos and the church. The idea is that of the plan of God being completed in the cosmos and the church. The emphasis is upon completeness - full number, full measure, fullness, completeness, totality' (Louw \& Nida 1984:59.32). The task of oixovouía in Ephesians (Eph 1:10, 3:2 \& 9) is more than a position or office of administration. It is part of the unifying work of Christ (Eph 1:10) that Paul is involved in that will be fulfilled or completed with the unification of the cosmos (Eph 1:20-23). The general tendency is to interpret the meaning of $\pi \lambda \eta^{\prime} \omega \mu \alpha$ in a literal sense, to mean "fullness" and "filling" (Eph 1:23) which has sparked theological debates about the meaning as either Christ completing the

17 "In the context the emphasis is on the more detailed description of the Body of Christ as the fullness of him who fills everything in the cosmos" (Schnakenburg 1991:80).

18 The present participle, "filling", in the Middle Voice could have an active or passive sense "(cf. Schnakenburg 1991:81). 
church or the church completing Christ. However, when the sense of $\pi \lambda \eta^{\prime} \rho \omega \mu \alpha$ is taken to be "completeness" and it is read against the context of the unfolding plan of God (Eph 1:10) new alternatives in a debate opens. The literal meaning of "to fill" has led to the notion that the cosmos and the church are perceived to be empty containers to be filled. In the context God gave Christ to the Church who completes the Church. He completes the mission of the Church. He completes the Church so that it can fulfill or complete its mission. The concept of $\pi \lambda \dot{n} \rho \omega \mu \alpha$ indicates that God's plan is to bring all of creation to the completeness of the New Creation. The church experiences the fullness of Christ and is thus enabled to participate in the mission of God. It is as the church reaches out with the gospel that Christ completes the church by including more and more diverse nations, cultures, people and language groups into the church. Christ continues to fill the church with his fullness (Eph 1:23) so that the church can be complete ${ }^{19}$.

\subsubsection{The Holy Spirit, the mission of the Church, and the mission of the God}

"The missio Dei is also the missio Spiritus since it is through the person and work of the Holy Spirit that the gospel is made known to the ends of the earth" (Yong 2010:48) ${ }^{20}$. Paul entrusts the "stewardship of the mystery" to the Church in the knowledge that it is the Holy Spirit who is the agent that accomplishes the missio Dei. The mission of the church is the work of the Holy Spirit. It is through the sovereign Spirit, who is the Lord of the Church, that the missio Dei, the mission of the apostles and the mission of the Church are united. The Holy Spirit continues the mission of Christ through the manifestation of the presence and power of the risen Christ in the apostolic mission and the church's mission" ${ }^{21}$ "The Spirit ensures that the church's mission will be politically engages rather than politically complicit" (Yong 2010:57). "The Incarnation as a model for mission has been argued as a basis for missionary identification, holistic ministry, liberation, contextualization of the church, and manifesting the life of Christ" (Cheong 2013:39). Hesselgrave cautions against using Stott's incarnationalism as the model for mission (cf. Cheong 2013:41). He argues that it wrongly focuses "on continuity between Christ's incarnate earthly ministry and the contemporary ministry of the church today" (Cheong 2013:41). It is through the Spirit that participation in Christ's risen presence as the power of mission is possible. In the prayer to the Ephesians (1:15-23), the Holy

${ }^{19}$ Christ completes the mission of the Church rather than fills the Church in a special way with his presence. It is in Colossians 1:19, 2:9 that Christ fills the Church with the fullness of the divine reality which is also the meaning in Ephesians 3:19.

${ }^{20}$ It is the power of the Spirit that produces the indigenous churches (cf. Yong 2010:48).

${ }^{21}$ The central mission of John is Jesus' mission and not the disciples (cf. Cheong 2013:53). "Every other mission is derivative of his: the Baptizer's, the Spirit's and the disciples" (Köstenberger 1998:141). 
Spirit is the spirit of wisdom and revelation, giving a fuller knowledge of Christ (Eph 1:17), spiritual perception describes as "having been enlightened the eyes of the heart" (Eph 1:18), revealing "the surpassing greatness of the power to us the ones believing" (Eph 1:19), indicating that the Spirit is at work in believers. The power or strength is available not merely for personal appropriation of "the hope of the calling of Him" (Eph 1:18), but also to empower the church to accomplish the mission it has received. The working of his mighty strength is the same working "which He exerted in Christ having raised him from the dead" (Eph 1:20). The power that is active in the church is comparable to the working of God's mighty strength (Eph 1:20-21) (cf. Padilla 2010:211). "The mission of the church is the historical manifestation of that power through word and deed, in the power of the Holy Spirit" (Padilla 2010:211).

\subsubsection{The calling of the believer}

The calling in Ephesians, unlike Romans, is not soteriological but a calling to participation in the missio Dei. In Romans 8:30 the term $\varkappa a \lambda \varepsilon$ '́ is used "in order to tell such a person to come - 'to call, to summon" (Louw \& Nida 1984:33.299-33.306), but in Ephesians $x a \lambda \varepsilon \varepsilon^{\omega} ; x \lambda \tilde{\eta} \sigma$ เs is used "to urgently invite someone to accept responsibilities for a particular task, implying a new relationship to the one who does the calling — 'to call, to call to a task." (Louw \& Nida 1984:33.312). In Romans 8:30 the term $x a \lambda \varepsilon^{\prime} \omega$ is used for a call to salvation, a soteriological call, and in Ephesians 1:18 $x a \lambda \varepsilon^{\prime} \omega$ is used in the sense of a call to a task, and so a missiological call ${ }^{22}$. The calling in Ephesians is for the church to fulfill its role in the mission of God, to participate in the missio Dei. "God's mission flows from God to Christ to the Holy Spirit, who empowers the church, who carries on the mission to the world" (Van Rheenan 2014:70). In the mission of the church individual Christians embody God's mission and are empowered by the Holy Spirit to convey it to the world.

\section{The relation of $\pi \lambda \eta^{\prime} \rho \omega \mu \alpha$ to Christ, the Church and the Cosmos}

The cosmic unity and re-unification is progressive and the final result is certain, Christ will fill or complete "all with all" (Eph 1:23). The verb $\pi \lambda \eta p o u \mu \varepsilon ́ v o v$ is a participle indicating that the "filling" or "completion" is God's plan rather than the cosmos being conceived is an empty space that is being filled. The cosmos is not a container that is being filled with Christ's presence implying that his presence somehow insufficient and limited. It is the dynamic presence of Christ throughout the cosmos that will cul-

${ }^{22}$ It is affirmed by the use of $x a \lambda \varepsilon$ ć elsewhere in Ephesians, "walk or live worthy of the calling" (Eph 4:1). The call in Ephesians 4:1 is not a soteriological call that is in view. The call "to live a worthy life" in the context is call to a missional lifestyle rather than indicating the necessity "to live a worthy life" as essential ingredient of salvation. 
minate in "the summing up of all things." (Eph 1:10). The cosmic unification is the bringing of harmony between the heavenly and earthly spheres (cf. Robersts1979:16). The church's mission is through its own renewal through a life of faith in the gospel to realize Christ's conquering of the powers which formerly ruled over them (cf. Eph 1:17; 2:2 (cf. Roberts 1979:16). The church is God's reconciled community to whom has been given the mission of reconciliation because in Christ re-unification has taken place. The church's mission of reconciliation should never be neglected (cf. Roberts 1979:17). In Colossians the emphasis is on the end of the process and views that cosmos as having been re-unified to Christ (Col 1:20-22) whereas in Ephesians Christ's exaltation to a position of rule high above any other source of rule is presented as a process (Eph 1:20-21) ${ }^{23}$. The church's mission is the proclamation of the message of reconciliation by means of which the world is being reconciled to him (Eph 2:16). "In her executing her mission, in bringing God's good news of reconciliation to a hostile world, she has to keep singing the praises of God until the enmity ceases and the world itself starts to join in her song of praise because God has indeed reconciled the world unto himself' (Roberts 1979:17).

\subsection{Reconciliation and mission of the Church}

The term $\varkappa \alpha \tau \alpha \lambda \alpha \dot{\alpha} \sigma \sigma \omega^{24}$ is used for personal reconciliation (Eph 2:16; Rom 5:10; 11:15), but also for "the reconciliation of all things" (Col 1:20), for cosmic unification. The church thus participates in the reconciliation of the cosmos through its proclamation of a message of personal reconciliation (2 Cor 5:18-20). The powers and principalities are identified as part of "the all things" which have been and are being subordinated under the feet of Christ (Eph 1:22). It is the relation of the exalted Christ to the church and the church's relation to the powers and principalities in the execution of its mission that is the focus of Ephesians 1:20-23.

\section{Conclusion}

In the letter to the Ephesians a relation exists between the mission of God and the mission of the church. The use of the concept oixovopia in Ephesians provides a structured basis for missions and corresponds to a missiology for foreign missions. The use of $\pi \lambda \eta^{\prime} \rho \omega \mu \alpha$ reflects the relationship between Christ and the church and corresponds to a theology of foreign missions. The term oixovouía is used in the sense of the "ongoing execution of the plan of God" (van Aarde 2015:52-53). It provides the continuity between the missio Dei (Eph 1:3-14, 1:10), the apostolic mission (Eph 3:2-8) and the church's mission (Eph 3:9-10). The author through the use of

\footnotetext{
${ }^{23}$ This is the verbal aspect.

24 It appears in the Pauline literature in only five contexts, viz. Rom 5:10, 11; 11:15; 2 Cor 5:18-20; Eph 2:16 and Col 1:20-22 (cf. Roberts 1979:8).
} 
oixovouia demonstrates that a relation exists between Christ' continuing work (Eph 1:10, 1-14), the apostolic mission (Eph 3:2, 3-8) and the church's mission (Eph 3:9-10). The term $\pi \lambda \eta^{\prime} \rho \omega \mu \alpha$ is used in the context of Ephesians 1:20-23 to indicate that the reign and kingdom of God and the Church are bound together. The relation of oixovo $\mu$ ia to $\pi \lambda \eta \dot{p} \rho \mu \alpha$ indicates that the Church plays a central role in the realization of the reign and kingdom of God and the completion of the mission of God. The task of the completion of the mission of God has specifically been given to the Church. The Church is God's primary instrument for "the summing up of all things" (Eph 1:10) and the "fulling" or "completion of all things" (Eph 1:23). It is not the "filling" of the cosmos or the Church that the author has in mind but the "completion" of the plan of God in "the fullness of the times" (Eph 1:10). Mission is the task of the whole church involving all God's people through participation in the fulfillment or completion of God's purposes (Eph 3:9-10). It is the progressive realization of the unity of the Christian ekklēsia through the inclusion of ethnē as a sign of the all-embracing cosmic unity (Eph 1:20-23). It is the crucial importance of the church-centered view of mission that is reaffirmed by the relation of oixovo $\mu i^{\alpha} \alpha$ and $\pi \lambda \eta^{\prime} \rho \omega \mu \alpha$ and the mission of God and the mission of the church.

\section{References}

Bassham, R.C., 1990. Mission theology - 1948-1975. Occasional Bulletin (1990):52-Aprl Bosch, D.J. 1991. Transforming missions: paradigm shifts in theology of mission. NewYork: Maryknoll.

Bowers, W.P. 1987. Fulfilling the gospel: the scope of the Pauline mission," JETS, 30(1987): 185-198. 3

Campbell, C.R. 2008. Basics of verbal aspect in biblical Greek. Grand Raids: Zondervan. Cheong, J. 2013. Reasessing John Stott;s, David Hesselgraves, and Andreas Köstenbergers Views on Incarnational Model. in Missionary methods: research, reflections, and realities, edited by Ott, C, \& Payne, J.D., Evangelical Missiological Society: William Carey Library: 38-60.

Edwards, J. 1972. The works of Jonathan Edwards. Edited by Smith, J.E et. Vol. 8. Ethical writings. New Haven: Yale University Press.

Engelsviken, T. 2003. Missio dei: the understanding and misunderstanding of a theological concept in European churches \& missiology. International Review of Mission. Vol. XCII 92(2003): 481-497.

Grizzle, J.B. 1997. Ephesians: Pentecostal commentary series. Dorest: Deo Publications. Payne, E.A., and Moses, D.G. 1957. Why integration? an explanation of the proposal before the WCC and the IMC. London: Edinburgh House Press.

Gallagher, R.L. 2013. Missionary methods: St. Paul's, St Roland's, or Ours? in Missionary methods: research, reflections, and realities, edited by Ott, C, \& Payne, J.D., Evangelical Missiological Society: William Carey Library: 3-22. 
Greenwood, R. 2002. Transforming church: liberating strategies for ministry. Society for Promoting Christian Knowledge: Holy Trinity Church.

Healey, N.M. 2000. Church, world and the Christian life: practical-prophetic ecclesiology. Cambridge: Cambridge University Press.

Hirsch, A. with Altclass, D. 2009. The forgotten ways handbook. Grand Rapids: Brazos Press. Hoehner, H.W., 2004. Ephesians: an exegetical commentary. Grand Rapids: Baker Academic. Jordaan, G.J.C., 1990. Die verbouding tussen indikatief en paaraklese in die brief aan die Efesiërs. In die Skriflig 24(1): 49-69, Mar.

Kirk, J.A., ed. 1999. What is mission? theological explorations. London: Longman and Todd. Köstenberger, A.J. 1998. The mission of Jesus and the disciples according to the Forth Gospel. Grand Rapids: Eerdmans.

Louw, J.P., \& Nida, E.A. 1996. Greek-English lexicon of the New Testament: based on semantic domains. New York: United Bible Societies.

Lust, J. Eynikel, E., \& Hauspie, K. (eds). 1991-1996. A Greek-English lexicon of the Septuagint. Parts 1 \& II. Stutgart: Deutsche Biblegesellschaft.

MacDonald, M.Y. 2000. Colossians and Ephesians: sacra pagina series vol. 17. Minnesota: The Liturgical Press.

Schnackenburg, R. 1991. The epistle to the Ephesians: a commentary. T \& T Clark. Edinburg.

Seim, T.K. 2012. Interfacing house and church: converting housebold codes to church order. in Text, images, and Christians in the Greco-Roman world: a festschrift in honor of David Lee Balch. Eds. Niang, A.C., \& Osiek, C. Eugene, Oregon: Pickwick Publications.

Senior, D. \& Stuhlmuller, C. 1983. The biblical foundations for missions. Saint Louis: Concordia Publishing House.

Van Aarde, T.A. 2015. The use of oixovouía for the missional plan and purpose of God in Ephesians 1:3-14. Missionalia 43(1):45-62, Apr.

Van 'T Hof, I. P. C. 1972. Op zoek naar het geheim van de zending: in dialog met die wereldzendingsconferenties 1910-1963. Wageningen: Veenman.

Van Rheenan, G. with Parker, A. 1996, 2014. Missions: biblical foundations and contemporary strategies. 2nd. Ed. Grand Rapids: Zondervan.

Vethanayagamony, P. 2010. Mission from the rest to the west: The changing landscape of world Christianity and Christian mission. in Mission after Christendom: emergent themes in contemporary mission. Louisville: Westminster John Knox Press: 59-70.

Walls, A.F. 11 996. The missionary movement in Christian history: studies in the transmission of faith. Madryknoll, New York: Orbis.

Webber, R.E. 2002. The younger Evangelicals: facing the challenges of the new world. Grand Rapids: Baker Books.

Wolvaart, B. 1999-2013. How to interpret the Bible. Harpenden, U.K: Veritas College.

Yong, A. 2010. Many tongues, many practices: Pentecost and theology of mission at 2010. in Mission after Christendom: emergent themes in contemporary mission. Louisville: Westminster John Knox Press: 43-58.`s 